\title{
Eksplorasi Media Sebagai Edukasi Kesadaran Ruang Hidup di Daerah Bencana
}

\author{
Rahmatsyam Lakoro, Agus Sachari, Agung Eko Budi Waspodo, Setiawan Sabana \\ Program Doktor Ilmu Seni Rupa dan Desain, Fakultas Seni Rupa dan Desain, \\ Institut Teknologi Bandung \\ e-mail:djangkarock@gmail.com
}

\begin{abstract}
Abstrak-Media komunikasi visual yang diproduksi untuk edukasi kebencanaan telah banyak dikembangkan, baik oleh pemerintah maupun lembaga-lembaga independen yang bekerja secara sukarela. Penelitian ini bertujuan mengidentifikasi, memahami dan menjelaskan tentang kajian konten visual pada media edukasi kebencanaan dalam strategi penuturan transmedia. Media edukasi yang dikembangkan menggunakan strategi lewat budaya tutur masyarakat lokal seperti lewat lagu atau permainan rakyat, tapi belum diketahui seberapa baik pemahaman masyarakat menghadapi kondisi darurat saat bencana terjadi. Metode penelitian yang diterapkan adalah grounded theory dengan analisa deskriptif kualitatif. Grounded theory merupakan rancangan penelitian kualitatif dimana peneliti memunculkan penjelasan umum (teori) tentang proses, aksi atau interaksi yang dibentuk oleh sejumlah partisipan menggunakan model Kerucut Pengalaman Edgar Dale. Perkembangan teknologi yang dekat dengan pengguna memungkinkan berbagai peluang untuk mengambil peran dalam edukasi kebencanaan dan mitigasi. Penelitian akan menelusuri estetika formal desain konten edukasi mengenai mitigasi bencana sebagai upaya edukasi kebencanaan melalui berbagai kemungkinan dalam pendekatan komunikasi lewat bahasa visual dalam edukasi kebencanaan. Hasilnya merupakan rekomendasi dalam perancangan media edukasi mitigasi kebencanaan.
\end{abstract}

Kata Kunci: edukasi, kerucut pengalaman, media, mitigasi bencana

\begin{abstract}
The visual communication media produced for disaster education has been widely developed, both by government and independent agencies working on a voluntary basis. This study aims to identify, understand and explain the study of visual content on disaster education media in the strategy of transmedia. Some of the educational media that have been developed utilize the approach of local people's speech culture such as through songs or people's games, but it is not known how well the public understanding of the emergency situation when the disaster occurred. The research method is using grounded theory with qualitative descriptive analysis. Grounded theory is a qualitative research design in which the researcher generates a general explanation (theory) about the process, action or interaction formed by a number of participants using Dale's Cone of Experience model. Technological developments close to the user allow opportunities to take a role in disaster and mitigation education. The research will trace the formal aesthetics of educational content design on disaster mitigation as a disaster education effort through various possibilities in communication approach through visual language in disaster education. The results are recommendation for designing educational media for mitigation.
\end{abstract}

Keywords: cone of experience, disaster mitigation, education, and media

\section{PENDAHULUAN}

Kesadaran ruang hidup penting ditanamkan terutama bila dikaitkan dengan kesiapsiagaan menghadapi kondisi geografis Indonesia yang rentan bencana. Kendala edukasi bencana modern selama ini diantaranya adalah keyakinan tradisional pada figur-figur tradisional yang menjadikan proses evakuasi, pengungsian dan evakuasi yang berbasis pengetahuan modern mengalami hambatan budaya, maka kesadaran ruang hidup seharusnya bisa berdampingan untuk memberikan edukasi pada masyarakat tentang bahaya bencana tersebut. Menurut Badan Nasional Penanggulangan Bencana (BNPB), 92\% bencana di Indonesia yang tercatat dari tahun 1815 hingga 2017 adalah bencana hidrometeorologi. Bencana tersebut berdampak pada kerusakan infrastruktur, hambatan transportasi di darat dan laut, ketidakamanan energi, fluktuasi produksi pangan, dan kemunduran stabilitas ekonomi

Di sisi lain, ada fenomena kearifan lokal yang menunjang edukasi kebencanaan. Masyarakat Kepulauan Nias dan Pulau Simeleue yang tinggal di dekat laut mendapati air laut yang tiba-tiba surut dan segera membacanya sebagai gejala awal smong (tsunami dalam bahasa masyarakat Simeleue). Merekalah yang segera memberi peringatan warga lain untuk menjauh dari pantai dan mencapai tempat tinggi. Kesadaran akan ruang hidup mereka yang rentan tsunami mendorong beberapa pemimpin adat menginisiasi sendiri edukasi mitigasi bencana lewat budaya tutur. Salah satunya yang dikemas dalam syair gubahan Moh. Riswan R, tokoh adat Simeulue. Syair itu digubah sejak Pulau Simeleue diterpa tsunami pada 1907 dan memakan banyak korban jiwa [1]. Dalam rentang waktu 1907-2004, edukasi mitigasi bencana ditanamkan pada warga untuk dapat memiliki pengetahuan yang tersimpan di wilayah batin dan kebiasaan dalam menghadapi krisis seperti tsunami. Dengan skala bencana dan waktu yang hampir bersamaan dengan peristiwa tsunami tahun 2004 di bagian barat pulau Sumatera, sekitar 230,000 jiwa korban tsunami di Aceh terlalu besar dibanding 6 orang warga Pulau Simeleue yang menjadi korban jiwa.

Variasi kultural dari satu tempat dengan tempat lain membuat pendekatan dalam perencanaan penanganan bencana berbeda di setiap budaya. Mereka yang secara geografis hidup di daerah bencana umumnya memiliki perencanaan menghadapi bencana yang dijalankan secara tradisional. Pola dalam sebuah komunitas dan kelompok sosial dapat memengaruhi pola-pola pemberian bantuan. Kelompok budaya yang berbeda memiliki kepercayaan yang berbeda-beda pula tentang konsep kematian dan kehidupan dan seringkali merespon sebuah fenomena bencana dengan cara yang tidak diduga oleh orang modern [2]. 
Dalam kaitannya dengan audiens yang disasar dalam edukasi mitigasi bencana, belum ditemui konsep perancangan yang cukup komprehensif untuk menghadapi problem-problem komunikasi kebencanaan. Narasi besar terkait prinsip kebenaran dan kesejahteraan yang dianggap universal kurang mampu mengakomodasi keragaman kultural dan audiens di wilayah cincin api sehingga diperlukan sistem desain untuk setiap karakteristik yang berbeda. Desain pada media yang dikonsumsi publik belum mempertimbangkan peruntukan dari pesan tersebut sehingga baru bersifat informatif dan belum melakukan persuasi lebih jauh. Desain yang ditemukan dalam penelusuran awal kebanyakan bersifat generik dan kontennya untuk audiens yang digeneralisasi [3]. Kondisi ini kurang mendukung proses penanaman informasi yang bersifat kedaruratan menjadi kebiasaan dan membentuk budaya keselamatan sejak usia dini dimana kemandirian secara fisik dan psikis belum terbentuk. Di sisi lain penelitian desain yang berpusat pada manusia dapat memperkuat kemampuan desainer untuk membentuk budaya populer dan secara halus mentransmisikan nilai-nilai melalui desain [4]. Hal ini menjadi penting bagi desainer yang ingin melawan tekanan dari korporasi besar untuk menampilkan sisi baiknya dalam cara mentransformasikan kesadaran dari respon terkondisi menjadi partisipasi aktif.

Carter [5] membagi tahapan-tahapan tersebut dalam siklus kesiapsiagaan, bencana, tanggap darurat, pemulihan, pembangunan, pencegahan dan mitigasi. Tahap Pencegahan, Mitigasi dan Kesiapsiagaan termasuk dalam tahapan Pra Bencana (pre-disaster); Tahap Tanggap Darurat, Pemulihan, Pembangunan termasuk dalam tahapan Pasca Bencana (post-disaster).

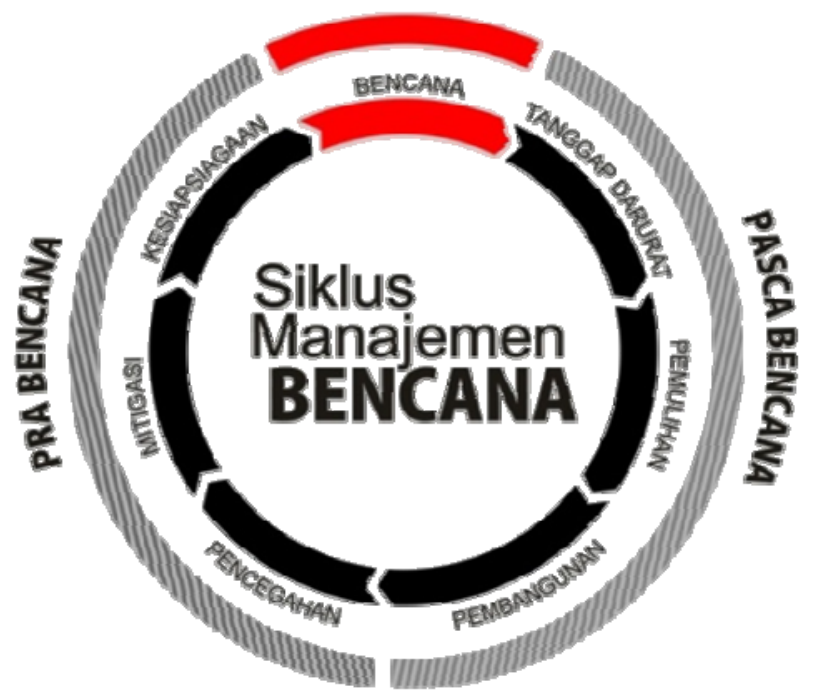

Gambar1 Siklus Manajemen Bencana (diadaptasi dari Carter, 2008)

Tahap Kesiapsiagaan berkaitan dengan kondisi saat indikator-indikator terjadinya bencana telah dapat diamati. Tahap Bencana merupakan even kejadian bencana yang diharapkan masyarakat telah siap siaga menghadapinya. Tahap Tanggap Darurat berkaitan dengan masa merespon bencana tersebut dengan sumber daya yang dimiliki sehingga jumlah korban dapat ditekan. Pada tahap ini pertolongan diberikan dalam situasi kedaruratan terkait kebutuhan dasar manusia. Tahap Pemulihan berkaitan dengan fase saat kejadian bencana sudah stabil sehingga dapat dilakukan pertolongan lebih lanjut. Tahap Pembangunan terkait berbagai upaya untuk membangun kembali kehidupan seperti kondisi sebelum bencana. Tahap Pencegahan berkaitan dengan upaya-upaya mencegah bencana terjadi lagi di tempat yang sama, dapat juga berupa antisipasi atas bencana yang mungkin terjadi. Tahap Mitigasi berkaitan dengan semua upaya untuk mengurangi resiko dan kerentanan yang muncul dari suatu bencana yang spesifik. Mitigasi bisa berupa tindakan terkait struktural bangunan, maupun kegiatan non struktural seperti edukasi dan pelatihan. Bila tahap ini berjalan dengan baik, masyarakat akan selalu dalam kondisi siap siaga menghadapi bencana.

\section{METODE}

Obyek yang dikaji adalah segala bentuk media komunikasi publik terkait mitigasi bencana baik yang bersifat cetak maupun elektronik, dengan memerhatikan aspek-aspek desain, komunikasi dan tataran ungkap dalam budaya visual yang memengaruhinya [6]. Bentuk umum media yang digunakan untuk edukasi mitigasi bencana selama ini dapat berupa poster, buku, film maupun animasi, hingga material yang dipergunakan dalam simulasi bencana. Subyek bencana yang dikaji dan dikembangkan dalam penelitian ini adalah bencana hidrometeorologi dan erupsi gunung berapi. Materi untuk sampel media yang digunakan adalah berbagai macam media edukasi mitigasi bencana yang dilansir oleh berbagai lembaga terkait penanganan bencana diantaranya BNPB, PMI, BASARNAS, BMKG, PPVMBG ESDM dan berbagai lembaga independen terkait.

Wilayah penelitian diambil sebagai sampel dalam lintasan wilayah cincin api dengan karakteristik bencana yang berbeda. Diharapkan dapat memberi gambaran bagaimana desain yang digunakan sebagai media edukasi mendekati audiensnya, serta kemampuannya dalam mengartikulasikan kearifan lokal. Subyek yang diteliti antara lain dari audiens yang disasar oleh edukasi bencana selama ini mulai dari pendidikan pra-sekolah hingga pendidikan dasar.

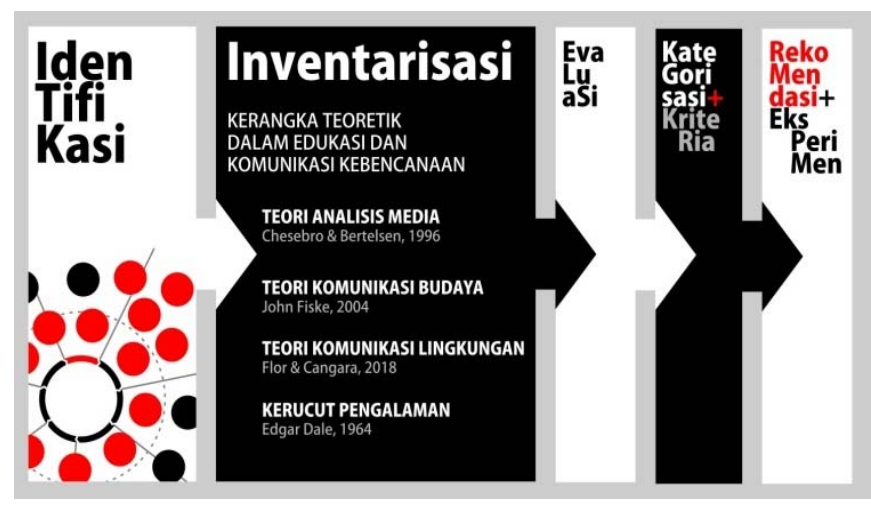

Gambar 2. Kerangka teoretik perancangan media edukasi mitigasi bencana

Diasumsikan dalam kelompok usia tersebut, audiens belum memiliki kemandirian secara fisik dalam mitigasi bencana. Subyek lainnya adalah wawancara dan diskusi kelompok terfokus dengan narasumber dari Badan Nasional Penanggulangan Bencana, komunitas Masyarakat Tangguh 
Bencana, dan penggiat Mitigasi Bencana untuk memperoleh gambaran tentang konsep-konsep yang dikembangkan terkait edukasi mitigasi bencana.

Media edukasi (educational media) dalam penelitian ini terkait dengan perangkat yang berhubungan langsung dengan kemampuan manusia berupa kemampuan kognitif, kapasitas berpikir dan kecerdasan. Secara esensial, media edukasi yang dimaksud dalam penelitian ini adalah media yang bertujuan untuk berkomunikasi, memfasilitasi ekspresi dan pertukaran ide antar individu. Media edukasi diidentifikasi sebagai berbagai alat yang digunakan untuk mendukung komunikasi antar manusia termasuk di dalamnya segala teknologi media edukasi yang diterapkan sebagai teknologi informasi dan komunikasi (TIK) melalui penggunaan perangkat dan aplikasi secara luas seperti telepon cerdas, sistem manajemen pembelajaran dan permainan elektronik [7].

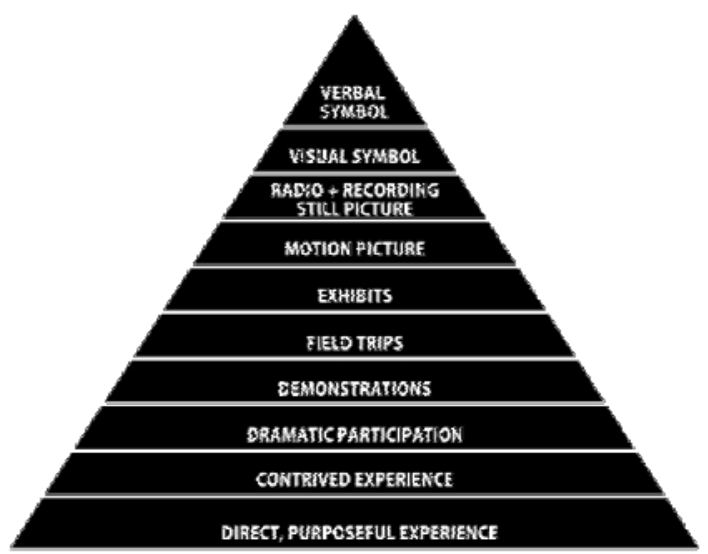

Gambar 3. Kerucut Pengalaman Edgar Dale yang memperlihatkan dampak belajar yang lebih menetap dengan pengalaman langsung yang bertujuan

Beberapa pengajaran menghasilkan pengetahuan yang cenderung menetap pada audiensnya selama bertahun-tahun sesudahnya. Pengalaman dari orang-orang yang diterpa pengajaran saat masih sangat muda yang kemudian mencerap momen yang tak terlupakan bagi sang murid jauh dan membekas bahkan ketika sudah dewasa [8]. Pemahaman yang cenderung permanen ini dibentuk oleh pengajaran yang menyentuh pengalaman yang dianggap penting oleh siswa/audiens. Pembelajaran efektif ini terkait informasi yang baru saja datang dengan hal-hal yang sudah mereka ketahui sebelumnya. Kondisi untuk menciptakan proses pembelajaran efektif ada tiga, yaitu ketika ada motivasi yang selayaknya menjadi alasan mengapa seseorang belajar; kejelasan tujuan dalam belajar tersebut; dan penggunaan media yang dapat mempengaruhi proses tersebut sehingga menjadi suatu proses belajar dapat membekas bila media/ sarana belajar dimanfaatkan dengan tepat. Belajar dari pengalaman nyata adalah pembelajaran yang paling kaya dan cenderung menetap lebih lama dibanding cara konvensional belajar dengan hanya membaca. Pada konsep yang telah diperbarui pada di edisi berikutnya, Dale membuat pembandingan dari dampak suatu media pembelajaran dalam kaitannya dengan apa yang dapat diingat oleh siswa serta dampak terhadap kompetensinya sebagai hasil belajar, dimana dengan belajar dari pengalaman yang kaya seseorang dapat mendefinisikan, menganalisa, mengevaluasi bahkan membuat sesuatu. Pengalaman langsung dan bertujuan (direct, purposeful experiences) akan membekas lebih kuat pada diri seseorang dibandingkan belajar dengan metode simbol verbal seperti membaca.

\section{HASIL DAN PEMBAHASAN}

Sampel yang dikaji dalam tulisan ini mengacu pada media edukasi berikut sesuai variabel desain yang diamati, dikaitkan dengan konten dan bagaimana penggunanya dapat belajar.

Tabel 1. Analisis media sampel web komik

\begin{tabular}{|c|}
\hline Media \\
\hline $\begin{array}{c}\text { Komik online edukasi bencana di portal KemenESDM } \\
\text { (www.portal.vsi.esdm.go.id/joomla) } \\
\text { Media daring laman internet }\end{array}$ \\
\hline Variabel Desain \\
\hline $\begin{array}{l}\text { Komposisi secara umum menggunakan kaidah komposisi dalam panel komik } \\
\text { dengan penekanan pada beberapa panel yang diperbesar dengan teknik } \\
\text { establishment shot } \\
\text { Warna menggunakan teknik pewarnaan manual dan cenderung menyerupai gaya } \\
\text { mewarna anak-anak untuk menyesuaikan kelompok pembaca } \\
\text { Tipografi teks mendukung narasi cerita dengan balon dialog yang sangat sedikit } \\
\text { Ilustrasi menggunakan gaya gambar anak-anak dengan proporsi anatomi chibi } \\
\text { juga diperkuat dengan lansekap bencana yang disederhanakan } \\
\text { Kode bunyi tidak ada }\end{array}$ \\
\hline Konten \\
\hline $\begin{array}{l}\text { Desain karakter ditujukan pada anak SD usia dini dimana kemampuan membaca } \\
\text { belum terlalu baik sehingga pesan dirancang dengan memakai karakter sebagai } \\
\text { pembawa pesan, dimunculkan karakter anak-anak yang penuh rasa ingin tahu pada } \\
\text { fenomena alam } \\
\text { Diagram proses ditampilkan dalam beberapa panel untuk memudahkan audiens } \\
\text { memahami pesan, seperti diagram lapisan bumi atau proses terjadinya suatu } \\
\text { bencana }\end{array}$ \\
\hline
\end{tabular}

Tabel 2. Analisis media sampel permainan elektronik

\begin{tabular}{l}
\hline Media \\
\hline Aplikasi permainan unduhan laman pengembang \\
\hline Variabel Desain \\
Komposisi berbentuk grid yang terdiri dari ikon-ikon berupa obyek-obyek terkait \\
keselamatan pada situasi darurat \\
Warna menggunakan palet warna tropikal sesuai dengan area distribusi permainan \\
Tipografi headline berupa judul permainan dan informasi terkait permainan dalam \\
palet huruf tanpa kait \\
Ilustrasi menggunakan gaya gambar ikonik dengan pewarnaan opaque \\
Kode bunyi respon pada ikon, suara latar dan komentar/ respon atas performa \\
pemain
\end{tabular}


Tabel 3. Analisis media sampel stiker

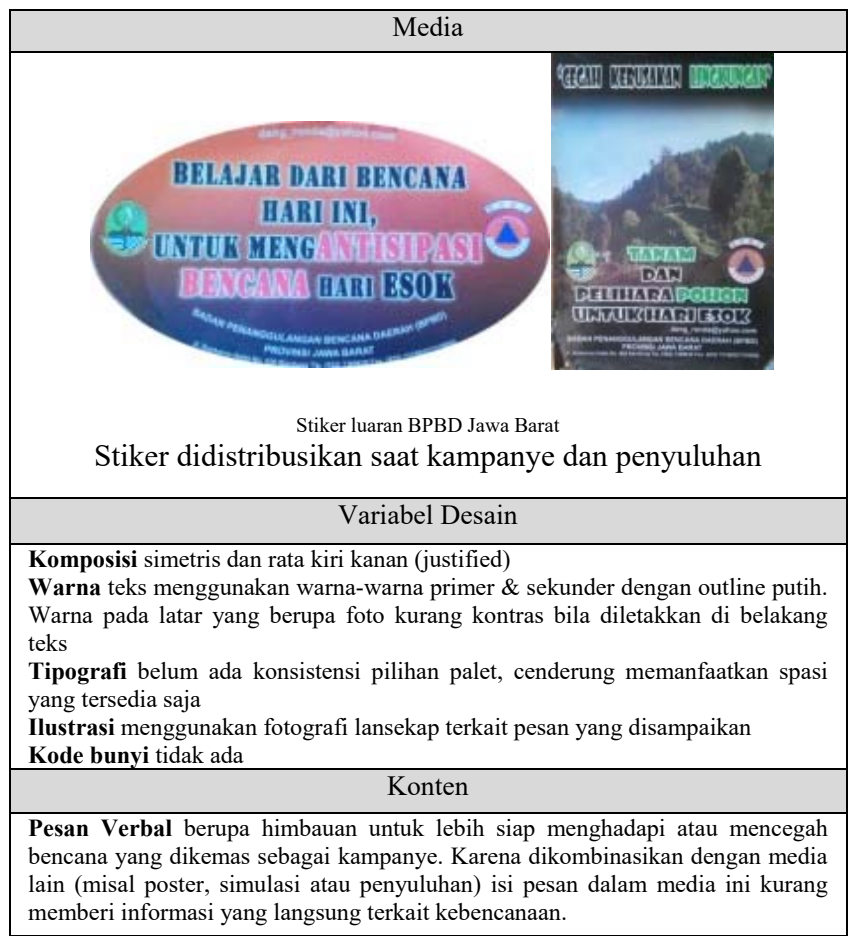

Tabel 4. Analisis media sampel komik sains

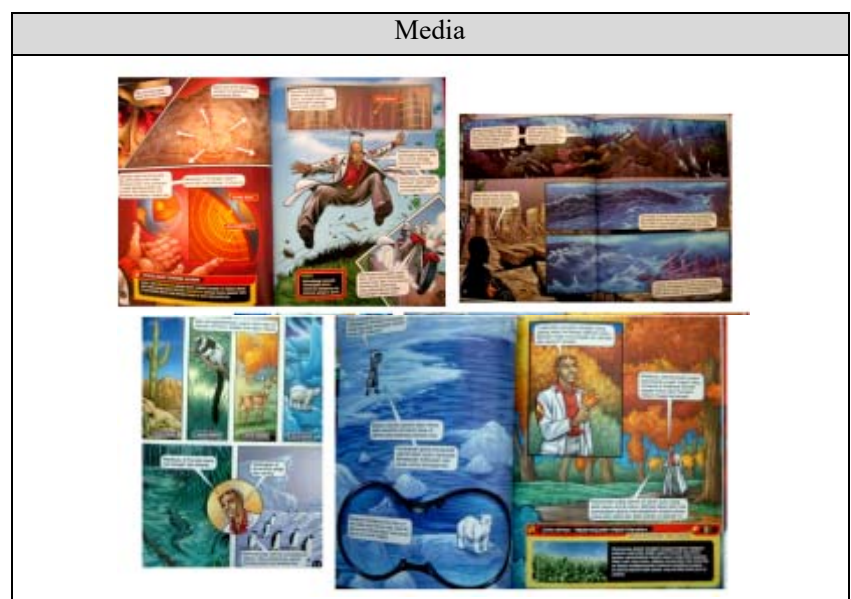

Komik Max Axiom (Agniezka Biskup, Chyntia Martin dan Bill Anderson

Komik sains serial (Graphic Science) Variabel Desain

Komposisi secara umum menggunakan kaidah komposisi dalam panel komik dengan penekanan pada beberapa panel yang diperbesar dengan teknik establishment shot

Warna menggunakan teknik pewarnaan digital dengan warna-warna yang kontras, cahaya dengan intensitas tertinggi dan bayangan nampak saling menguatkan bentuk

Tipografi teks mendukung narasi cerita dengan balon dialog dan narasi sesuai kepadatan cerita

Ilustrasi menggunakan gaya gambar komik Amerika pada umumnya dengan outline tebal dan pewarnaan yang didramatisasi sesuai tuntutan naskah, banyak pula digambarkan lansekap dengan pewarnaan yang dramatis Kode bunyi tidak ada

\section{Konten}

Desain karakter utama adalah seorang ilmuwan yang memiliki kekuatan super, digambarkan dalam proporsi yang heroik khas karakter komik super hero Amerika. Toko ini yang menjelaskan proses-proses alami dari suatu bencana dengan bahasa yang sederhana dan mengambil contoh di sekeliling target audiens (anak-anak usia madya)

Naskah dirancang berdasar pengalaman karakter utama sebagai ilmuwan yang mendeskripsikan setiap fenomena alam

Diagram proses ditampilkan dalam beberapa panel untuk memudahkan audiens memahami pesan, seperti diagram lapisan bumi atau proses terjadinya suatu bencana (terdiri dari beberapa seri buku)
Tabel 5. Analisis media sampel aplikasi telepon cerdas

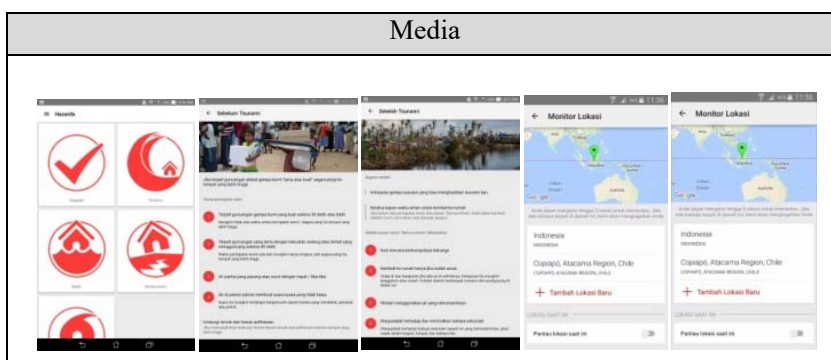

Aplikasi Siaga Bencana dikembangkan PMI (playstore)

Aplikasi telepon cerdas di Play Store (5000+ unduhan)

\section{Variabel Desain}

Komposisi menggunakan komposisi linear dengan beberapa ikon untuk menekankan informasi yang dapat diakses

Warna didominasi warna putih dengan aksen merah pada ikon dan beberapa teks untuk keterbacaan dan indikator kedaruratan

Tipografi teks dari palet huruf tanpa kait yang memiliki keterbacaan tinggi

Ilustrasi hanya diterapkan pada ikon dan beberapa potong foto untuk menggambarkan kondisi bencana

Kode bunyi berupa respon pada ikon yang diakses

$$
\text { Konten }
$$

Interaktifitas dalam konten memberi kesempatan pengguna untuk menguji seberapa baik pemahaman akan bencana dalam menu yang serupa kuis. Pengguna juga dapat melaporkan kondisi darurat di sekitarnya. Ada pula menu info tentang tas siaga

Ikon dalam aplikasi dirancang dalam ukuran besar pada layar menu utama dengan info utama terkait tsunami, banjir, gempabumi, badai topan dan kesiagaan. Pengguna diminta mengisi lokasi tinggal pada awal penggunaan aplikasi utuk memudahkan penyampaian informasi yang relevan secara geografis

Tabel 6. Analisis media sampel animasi

(17) SIAP SIAGA

Animasi oleh Humas BNPB

Animasi Siaga Bencana 2D di akun Youtube Humas BNPB Edisi ini telah dilihat oleh 49,937 audiens

\section{Variabel Desain}

Komposisi secara umum menggunakan kaidah komposisi dalam animasi yang mengacu pada sinematografi dimana layar sebagai ruang ungkap. Umumnya obyek diberi penekanan seperti lampu sorot atau penekanan pada gerak tertentu, serta permainan longshot-close up Warna menggunakan palet warna biru sebagai warna dominan hampir disetiap seri juga sebagai warna identitas kampanye ini. Warna lain hadir sebagai aksen pada tampilan keseluruhan

Tipografi teks digunakan pada judul (semua judulnya terkait gejala akan terjadinya suatu bencana alam) dan digunakan pula untuk menekankan suatu informasi (misal: hotline bantuan)

Ilustrasi menggunakan gaya gambar vektor dengan penggambaran obyek yang disederhanakan, minimalis tetapi informatif bergaya animasi penjelas. Lokasi tidak spesifik dengan beberapa efek animasi yang cenderung fantasi

Kode bunyi narator membacakan naskah dan penekanan efek suara (alam/ buatan foley) pada bagian tertentu

$$
\text { Konten }
$$

Desain karakter yang sederhana dengan gestur yang mudah dipahami juga memiliki gaya khas di setiap seri yang muncul. Detil pada wajah dan tangan dihilangkan sehingga dapat berarti siapapun

Pesan Verbal ditampilkan sebagai gejala-gejala yang ditunjukkan oleh alam sebelum terjadinya suatu bencana, apa yang harus disiapkan, apa tindakan yang perlu diprioritaskan dan bagaimana cara meminta bantuan 
Tabel 7. Analisis media sampel film

\begin{tabular}{|c|}
\hline Media \\
\hline $\begin{array}{l}\text { Lagu "Kalau ada Gempa" } \\
\text { KACA ADA GEMPA } \\
\text { Kanal edukasi Ayo Mendidik di Youtube } \\
\text { Edisi gempa ini telah dilihat oleh } 12,118 \text { audiens }\end{array}$ \\
\hline Variabel Desain \\
\hline $\begin{array}{l}\text { Komposisi secara umum menggunakan kaidah komposisi dalam film } \\
\text { documenter dengan teknik-teknik sinematografi dimana layar sebagai } \\
\text { ruang ungkap (mise en scene). Adegan banyak bersifat demonstratif } \\
\text { tentang lagu untuk edukasi gempa } \\
\text { Warna belum menggunakan koreksi warna untuk memperoleh warna } \\
\text { yang khas, masih bersifat dokumentatif saja } \\
\text { Tipografi teks digunakan pada judul saja } \\
\text { Ilustrasi tidak ada } \\
\text { Kode bunyi lagu yang mengekspos pendidikan mitigasi melalui syair } \\
\text { lagu "Kalau Ada Gempa" yang mengadaptasi lagu anak populer }\end{array}$ \\
\hline Konten \\
\hline $\begin{array}{l}\text { Desain karakter utama adalah seorang narator yang menjelaskan } \\
\text { fenomena alam secara jenaka, sesekali berinteraksi dengan konten } \\
\text { animasi melalui teknik-teknik motion graphic. Narator juga } \\
\text { digambarkan sebagai animasi yang dapat berinteraksi dengan subyek } \\
\text { yang sedang dijelaskan. } \\
\text { Pesan Verbal dikemas sebagai kursus singkat, sehingga informasi } \\
\text { tentang apa yang harus dilakukan saat gempa disampaikan lewat lagu } \\
\text { anak popular dan dapat diingat dengan mudah }\end{array}$ \\
\hline
\end{tabular}

Tabel 8. Analisis media sampel aplikasi telepon cerdas

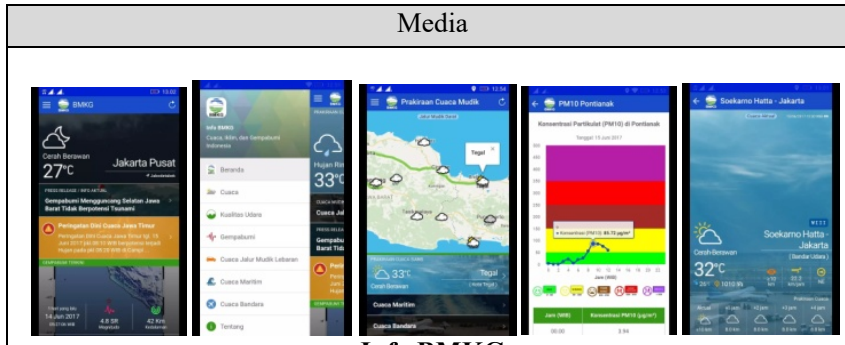

Info BMKG

Pengembang: BMKG

Pengguna: 1 juta-an / 19 Januari 2018

Rating di Playstore: 4.2 / 18,765 pengguna

\section{Variabel Desain}

Media berupa aplikasi informasi cuaca dan geospasial yang juga sekaligus informasi terkait kebencanaan.

Komposisi menggunakan komposisi linear dengan beberapa ikon untuk menekankan informasi yang dapat diakses

Warna didominasi warna hitam dan biru dengan aksen coklat amber dan hijau pada beberapa teks untuk keterbacaan dan indikator kedaruratan

Tipografi teks dari palet huruf tanpa kait yang memiliki keterbacaan tinggi

Ilustrasi hanya diterapkan pada ikon untuk menu dan indikator cuaca dan penggambaran notasi yang diambil dari citra satelit. Tidak menunjukkan ruang hidup tertentu selain penggambaran berbentuk diagram-diagram informasi

Kode bunyi berupa respon pada ikon yang diakses Konten

Interaktifitas dalam konten memberi kesempatan pengguna untuk menguji seberapa baik pemahaman akan bencana dalam menu yang serupa kuis. Pengguna juga dapat melaporkan kondisi darurat di sekitarnya.

Ikon dalam aplikasi dirancang dalam ukuran besar pada layar menu utama dengan info utama terkait tsunami, banjir, gempabumi, badai topan dan kesiagaan. Pengguna diminta mengisi lokasi tinggal pada awal penggunaan aplikasi utuk memudahkan penyampaian informasi yang relevan secara geografi

Teknologi memanfaatkan teknologi geospatial yang bisa diakses meskipun tidak real time. Memiliki kemampuan menggambarkan kondisi cuaca dalam rentang waktu yang cukup akurat. Bahasa penyajian terlampau canggih untuk audiens usia anak-anak.

\section{KESIMPULAN/RINGKASAN}

Sampel yang diambil pada penelitian awal ini memperlihatkan keragaman pendekatan, baik secara visual maupun verbal. Selain pendekatan bahasa yang digunakan, target audiens yang banyak dilayani dalam edukasi dan informasi kebencanaan adalah anak-anak usia madya.

Gaya visual yang digunakan dan kompeksitas informasi yang diberikan secara keseluruhan media menampilkan ruang hidup yang beragam baik secara simbolik dan kartunal maupun fotografis agar kondisi bencana menjadi lebih visual. Hal ini bisa menciptakan jarak antara informasi dan ruang hidup yang ingin disajikan dekat dengan audiens.

Aspek bahasa yang muncul pada sampel cenderung terlau canggih, saintifik dan spesifik untuk target audiens usia anak-anak, sehingga peruntukannya kebanyakan pada pengguna yang lebih lanjut. Pendekatan pada audiens tersebut cenderung didominasi oleh bahasa yang lebih visual yang sederhana dengan warna-warna yang populer di kalangan usia tersebut.

\section{UCAPAN TERIMA KASIH}

Terimakasih kepada Pimpinan ITS, rekan-rekan diskusi di Masyarakat Tangguh Indonesia, Kepala Departemen Desain Produk Industri ITS, Kepala Departemen Desain Komunikasi Visual ITS dan rekan-rekan diskusi yang kritis di FSRD ITB.

\section{DAFTAR PUSTAKA}

[1] Karokaro, Ayat S. (2014) Kearifan Lokal Selamatkan Warga Simeulue dari Amukan Tsunami (bagian 1), Mongabay, http://www.mongabay.co.id (20 December 2014)

[2] Ehrenreich, John H.(2001). Coping With Disasters: A Guidebook To Psychosocial Intervention (Revised Edition), Sharon McQuaide, M.S.W., Ph.D. Clinical Consultant

[3] Lakoro, Rahmatsyam (2017). Design of Education Media For Disaster As Awareness of Life Space In Disaster Area, International Conference on Creative Industry 4 (2), 142 -145.

[4] Laurel, Brenda (ed.)(2003). Design Research: Methods and Perspectives, (hal.13-17). Massachusetts: MIT Press

[5] Carter, W. Nick (2008). Disaster Management Handbook, Mandaluyong City, Philipine: Asian Development Bank

[6] Chesebro, James W., Dale E. Bertelsen (1996) Analyzing Media, New York: The Guildford Press

[7] Haryanto, Hanny \& Lakoro, Rahmatsyam (2012). Game Edukasi "Evakuator"Bergenre Puzzle dengan Gameplay Berbasis Klasifikasi sebagai Sarana Pendidikan Dalam Mitigasi Bencana, Techno.COM, Vol 11 No. 1, February 2012: 47-54.

[8] Dale, Edgar (1946). Audio-Visual Methods in Teaching, (hal 38-43). New York: Dryden Press 